\title{
The up-to-date heat pump-combined heat and power solution for the complete utilization of the low enthalpy geothermal water potential
}

\author{
Sorin Dimitriu • Ana-Maria Bianchi • \\ Florin Băltăreţu
}

Received: 25 June 2014/ Accepted: 16 October 2014/Published online: 18 November 2014

(C) The Author(s) 2014. This article is published with open access at Springerlink.com

\begin{abstract}
The paper focuses on the thermal potential utilization of the geothermal resources from the Olt Valley (Romania, Calimanesti, Caciulata area). The three existing drills ensure low enthalpy geothermal water $\left(92-95^{\circ} \mathrm{C}\right)$ having, at the exit of the wells, a high content of combustible gases. The equivalent hot water thermal potential —without the use of the combustible gases-is used for heating several spa hotels and for the heat supply system of the urban area. At present, the gases from the geothermal water, having a rich content of methane $(88 \%)$, are released into the atmosphere. The paper proposes a solution concerning a complete valorisation of the energy potential of this geothermal water, using heat pumps and a highperformance micro gas turbine cogeneration unit. We highlight that it is possible to extend the exploitation of the geothermal energy by a viable solution, via which the investment can be recovered in a short time. This work provides a solution in total accordance with the frame of the European Directives regarding the increase in energy efficiency, the use of the renewable resources and the environment protection.
\end{abstract}

Keywords Geothermal water - Geothermal district heating $\cdot$ Micro gas turbine cogeneration

Published in the Special Issue "Energy, Environment, Economics and Thermodynamics".

S. Dimitriu $(\bowtie)$

"Politehnica" University Bucharest, Splaiul Independentei 313, 060042 Bucharest, Romania

e-mail: dimitriu47@yahoo.com

A.-M. Bianchi · F. Băltăreţu

Technical University of Civil Engineering Bucharest,

Bd. Pache Protopopescu 66, 021414 Bucharest, Romania

\section{Introduction}

Geothermal energy has been used for centuries, for spa treatments, preparing domestic hot water and heating. It reduces greenhouse gas emission, using an inexhaustible and continuously available source. The European renewable energy policy in this field has never been more important. Renewable energy plays a crucial role in reducing greenhouse gas emissions and other forms of pollution, diversifying and improving the security of energy supply. It is for this reason that the leaders of the European Union have agreed on legally binding national targets for increasing the share of renewable energy, so as to achieve a $20 \%$ share for the entire Union by 2020 [1].

It is worth noting that the problem of the integration of the renewable energy sources and micro cogeneration into a heating or a district heating system is of great interest worldwide. Examples of such applications concern hybrid micro-cogeneration systems (an internal combustion engine integrated with a high efficiency furnace) designed to satisfy both the thermal and power needs of a building [2], or renewable energy systems using low enthalpy geothermal energy for district heating [3].

In Romania, the geological research carried out between 1960 and 1980 has proved the existence of significant geothermal resources in some regions, mainly in the western part of the country, with an annual geothermal usable potential of about 7,000 TJ [4]. From the 250 drilling wells (450 MW) existing in Romania, at present only 80 are used (180 MW), at temperatures of $40-120^{\circ} \mathrm{C}$, with a $1,235 \mathrm{TJ}$ annual production. The main uses of geothermal waters are for district heating and the heating of individual buildings-especially in the western part of the country-balneology, recreation, greenhouses heating, fishing culture and industrial uses (drying cereals, wood, etc.) [5, 6]. In 


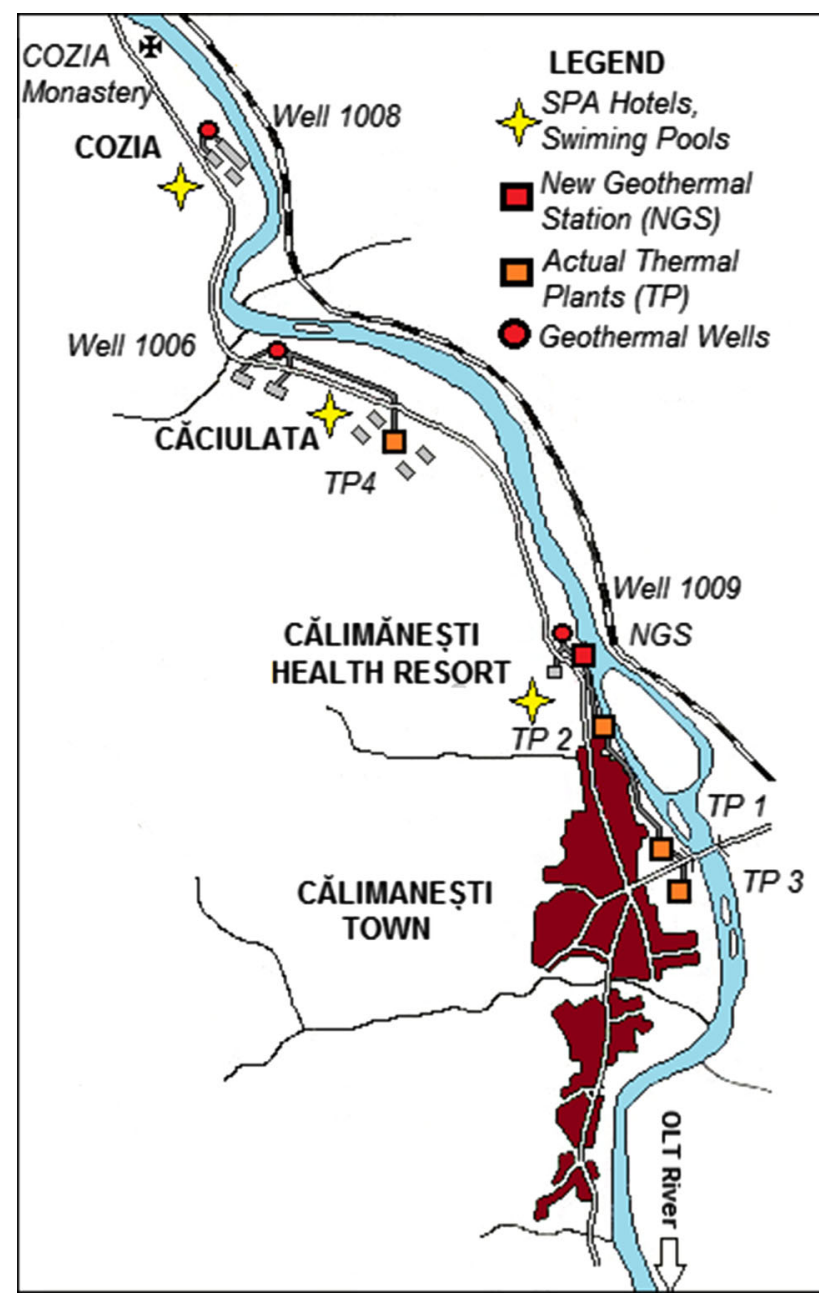

Fig. 1 Geothermal water wells on the Olt Valley

2003, the Romanian Government approved the "Strategy for the development of renewable energy sources", which sets short- and medium-term targets in accordance with the EU principles and directives. This government decision provides significant increases in research activities and investments to capitalize the geothermal potential with direct economic applications [7]. It has spurred concerns for efficient exploitation and utilization of the geothermal resources but the completion of the projects took a long time and great efforts, due to financial difficulties and problems with the existing laws. Practical projects of the last 10 years are rather modest, being located in some localities of the western part of the country and on the Olt Valley, Valcea County. These projects were intended either for modernising the equipment and management of the existing geothermal systems or for the exploitation of new reservoirs. Some of these projects have involved consultants from Western European countries and received financial support from the European Union [8].

Given these concerns, the objective of the present paper is to propose a modern solution for the utilization of the
Table 1 The composition and ratio of gases from the geothermal water [9]

\begin{tabular}{|c|c|c|c|}
\hline \multicolumn{4}{|l|}{ Geothermal water well } \\
\hline $\begin{array}{l}\text { The working } \\
\text { parameters of the } \\
\text { water boreholes at the } \\
\text { commissioning }\end{array}$ & $\begin{array}{l}\text { No. } 1006 \\
\text { Caciulata } \\
\text { Volume flow } \\
32.4 \mathrm{~m}^{3} / \mathrm{h} \\
\text { Temp. } 87^{\circ} \mathrm{C}\end{array}$ & $\begin{array}{l}\text { No. } 1008 \\
\text { Cozia } \\
\text { Volume flow } \\
57.6 \mathrm{~m}^{3} / \mathrm{h} \\
\text { Temp. } 89{ }^{\circ} \mathrm{C}\end{array}$ & $\begin{array}{l}\text { No. } 1009 \\
\text { Calimanesti } \\
\text { Volume flow } \\
28.8 \mathrm{~m}^{3} / \mathrm{h} \\
\text { Temp. } 85^{\circ} \mathrm{C}\end{array}$ \\
\hline \multicolumn{4}{|c|}{ The ratio of gases contained in the geothermal water $\left(\mathrm{m}_{\mathrm{N}}^{3} / \mathrm{m}^{3}\right.$ water $)$} \\
\hline Nitrogen $\left(\mathrm{N}_{2}\right)$ & 0.2638 & 0.2928 & 0.3254 \\
\hline $\begin{array}{l}\text { Carbon dioxide } \\
\left(\mathrm{CO}_{2}\right)\end{array}$ & 0.0247 & 0.0198 & 0.0264 \\
\hline Methane $\left(\mathrm{CH}_{4}\right)$ & 2.1561 & 1.6545 & 2.2389 \\
\hline Ethane $\left(\mathrm{C}_{2} \mathrm{H}_{6}\right)$ & 0.0200 & 0.0129 & 0.0193 \\
\hline Propane $\left(\mathrm{C}_{3} \mathrm{H}_{8}\right)$ & 0.0042 & 0.0032 & 0.0028 \\
\hline$i$-Butane $\left(\mathrm{C}_{4} \mathrm{H}_{10}\right)$ & 0.0002 & 0.0008 & 0.0003 \\
\hline$n$-Butane $\left(\mathrm{C}_{4} \mathrm{H}_{10}\right)$ & 0.0007 & 0.0010 & 0.0003 \\
\hline Total from which & 2.4697 & 1.9850 & 2.6404 \\
\hline $\begin{array}{l}\text { Combustible gases } \\
\text { ratio }\end{array}$ & $2.18(88 \%)$ & $1.67(84 \%)$ & $2.26(86 \%)$ \\
\hline $\operatorname{LHV}\left(\mathrm{MJ} / \mathrm{m}_{\mathrm{N}}^{3}\right)$ & 31.7 & 30.5 & 30.6 \\
\hline
\end{tabular}

energy potential of the geothermal resources, from the area around Calimanesti Town, Valcea County. In this area, the geothermal water is provided by three drillings located on the right-hand side of the Olt River, as presented in Fig. 1. The three existing drillings provide low enthalpy geothermal water, having the well exit temperature of about $95^{\circ} \mathrm{C}$, and a high content of combustible gases, especially methane. A project, developed in 2001-2002, aimed at integrating all geothermal resources from this perimeter into the heating system of Calimanesti Town [9]. Currently, only one of the wells provides the district heating system with geothermal water. Due to operating conditions, the geothermal water is cooled down only up to $50{ }^{\circ} \mathrm{C}$, its potential being incompletely exploited. To recover the entire thermal potential of the geothermal water, the article proposes the integration of a heat pump into the present centralized heating system and, at the same time, the recovery of the combustion heat of the gases, either by direct combustion in hot water boilers, or by their use in a micro gas turbine cogeneration unit.

\section{The energy potential of the gases from geothermal water}

Table 1 presents the composition and the amount of gases contained in geothermal water, according to analyses reported at the commissioning of boreholes [9]. The maximum available volume flow for the ensemble of the 
Table 2 The energy potential possibly to recover from the combustible gases

\begin{tabular}{llllll}
\hline $\begin{array}{l}\text { Geothermal } \\
\text { water well }\end{array}$ & $\begin{array}{l}\text { Water volume } \\
\text { flow }(\mathrm{l} / \mathrm{s})\end{array}$ & $\begin{array}{l}\text { Gas ratio } \\
\left(\mathrm{m}_{\mathrm{N}}^{3} / \mathrm{m}^{3} \text { water }\right)\end{array}$ & $\begin{array}{l}\text { Gas } \\
\text { temperature } \\
\left({ }^{\circ} \mathrm{C}\right)\end{array}$ & $\begin{array}{l}\text { Low heating value } \\
\left(\mathrm{MJ} / \mathrm{m}_{\mathrm{N}}^{3}\right)\end{array}$ & $\begin{array}{l}\text { Thermal } \\
\text { power }(\mathrm{kW})\end{array}$ \\
\hline Caciulata & 9.4 & 2.470 & 96 & 31.7 & 736 \\
Cozia & 23.0 & 1.985 & 92 & 30.5 & 1,392 \\
Calimanesti & 18.0 & 2.645 & 92 & 30.6 & 1,457 \\
Total & 50.4 & & & & 3,603 \\
\hline
\end{tabular}

three drillings is about $50.4 \mathrm{l} / \mathrm{s}$, which is equivalent to an effective thermal potential of 13.2 MW, if the geothermal water after its utilization reaches a temperature of $30{ }^{\circ} \mathrm{C}$. It can highlight, at all the three wells, a large amount of gases associated with the geothermal water, having a great content of methane (over $88 \%$ ) and a low heating value (LHV) of about $32 \mathrm{MJ} / \mathrm{m}_{\mathrm{N}}^{3}$.

Table 2 presents the energy potential likely to be recovered by burning the combustible gases from the whole flow of the hot water produced by the three existing wells. The available thermal power, at the full capacity of the wells, is about $3.6 \mathrm{MW}$.

The simplest solution to utilise this potential consists in the combustion of the gases directly, in the actual oil-fired hot water boilers, completely replacing the liquid fuel. Considering the hot water boilers efficiency of about $90 \%$, the value of the utilisable thermal potential is of about $3.2 \mathrm{MW}$, the existing heating system having the possibility to work without liquid fuel, taking into account only the burning of combustible gases. However, the best solution is to use the combustible gases to put into action micro gas turbines cogeneration units. In this way, it is possible to combine the production of thermal energy delivered to consumers, with the production of electricity used for pumping the thermal agent and to cover their own consumption. The local electric network may receive the excess electricity.

\section{Present utilization of geothermal resources}

The two geothermal boreholes far from Calimanesti Town, located near the localities Caciulata and Cozia (Fig. 1), are used for the local needs of a group of hotels and spa treatment units, for heating, domestic hot water and thermal pools. The third geothermal borehole, near Calimanesti Town, provides a maximum volume flow of geothermal water of $18 \mathrm{l} / \mathrm{s}$ at a temperature of $92-95{ }^{\circ} \mathrm{C}$ [9]. This locality has about 8,500 permanent inhabitants of whom $20 \%$ live in apartments connected to a centralized heating system; in the period of 2012/2013, 546 apartments were branched to this system, according to the official website of ANRSC [10]. According to data provided by the local authorities, the full thermal need of the town is about $4,000 \mathrm{~kW}$, of which $3,500 \mathrm{~kW}$ for heating and $500 \mathrm{~kW}$ for the preparation of domestic hot water. Initially, the heating system of the town was designed with three classic thermal plants, equipped with oil-fired hot water boilers, the geothermal hot water being used for spa treatment units and thermal pools only.

The project of geothermal energy supply started in 2002, initially with internal financing, and later supported by European funds. Initially, the project included the three wells to provide the centralized heating of Calimanesti town. Later, it utilized only the available water from the borehole No. 1009, situated near the town. Of the available volume flow of $18 \mathrm{l} / \mathrm{s}$, a spa centre and a hotel utilise about $8 \mathrm{l} / \mathrm{s}$, the rest of the volume flow, about $10 \mathrm{l} / \mathrm{s}$, supplies the centralized district heating system by means of a geothermal heating station, located just near the geothermal borehole (Fig. 1) which prepares the necessary thermal agent. The thermal agent, having the temperature of about $85^{\circ} \mathrm{C}$, is produced from geothermal water using two plate heat exchangers. The geothermal station with its scheme presented in Fig. 2, uses a plate heat exchanger (WPHE), which works continuously in all seasons, completely covering the thermal needs for domestic hot water preparation $(500 \mathrm{~kW})$, and another (HPHE) that works only in the cold season, when the heating system is on. Since the temperature of the thermal fluid, returned from the heat supply system, is about $45^{\circ} \mathrm{C}$, the geothermal water can be cooled only to $50{ }^{\circ} \mathrm{C}$, and flows into the Olt River with this temperature. In this way, the thermal potential of the geothermal water is not entirely used. Even under these circumstances, the use of geothermal water leads to the complete elimination of the liquid fuel for domestic hot water preparation and to the supply of about $40 \%$ of the thermal energy needs for heating $(1,320 \mathrm{~kW})$. The old oilfired hot water boilers cover the peaks and the rest of the thermal energy needs $(2,180 \mathrm{~kW})$. The real cost of the thermal energy produced from geothermal water is about $0.03 € / \mathrm{kWh}$, compared with $0.1 € / \mathrm{kWh}$ if the thermal energy is produced in oil fired plants only [10].

The primary energy ratio (PER) of this combined thermal energy supply system (geothermal and classic) can be determined with the expression:

$\mathrm{PER}=\frac{\dot{Q}}{\dot{Q}_{\mathrm{H}}^{\mathrm{HWB}}} \eta_{\mathrm{HWB}}$ 
Fig. 2 The operating scheme of the current geothermal station: $G W W$ geothermal water well, $D T$ degassing tank, $P S$ pumping station, WPHE plate heat exchanger for domestic hot water, $H P H E$ plate heat exchanger for heating

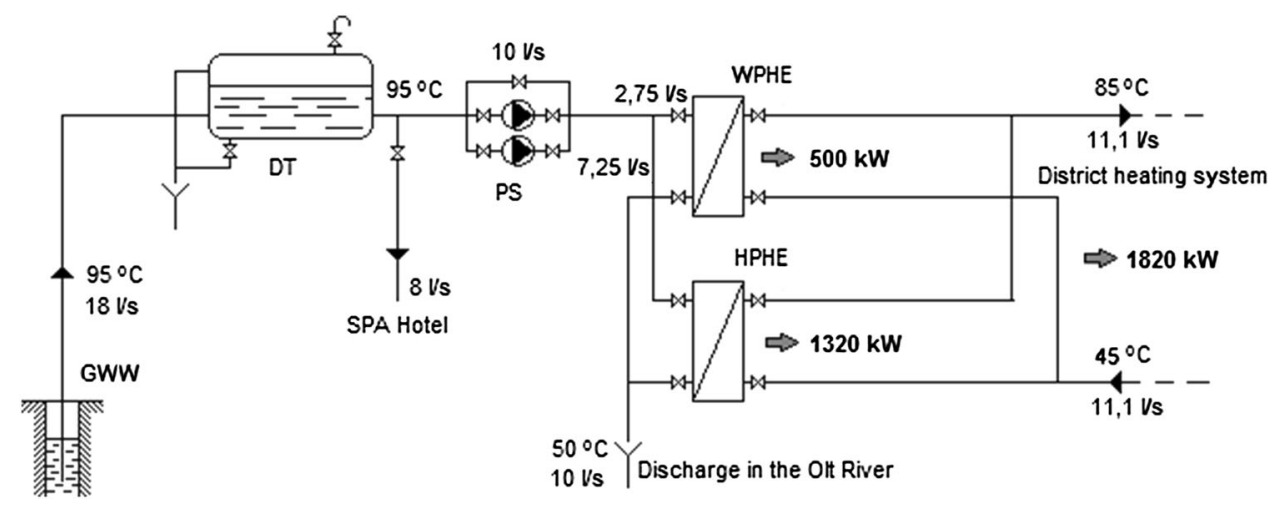

where $\dot{Q}[\mathrm{~kW}]$ is the total estimated thermal power for the heating system (domestic hot water production and heating), $\dot{Q}_{\mathrm{H}}^{\mathrm{HWB}}[\mathrm{kW}]$ represents the thermal power needs for heating provided only by the oil-fired hot water boilers and $\eta_{\text {HWB }}$ is the usual efficiency of the hot water boilers $\left(\eta_{\mathrm{HWB}}=0.88-0.92\right)$ [11]. Considering $\dot{Q}=4000 \mathrm{~kW}$ and $\dot{Q}_{\mathrm{H}}^{\mathrm{HWB}}=2180 \mathrm{~kW}$, the obtained value is $\mathrm{PER}=1.65$, which means an improvement of the system efficiency about $83 \%$ compared to the previous situation, when the total thermal energy for the heating system was produced only using liquid fuel (in this case $\mathrm{PER}=\eta_{\mathrm{HWB}} \cong 0.90$ ).

\section{The full recovery of the geothermal water potential, using a heat pump}

For a good recovery of the geothermal water potential, we propose a solution to recover the available thermal energy from the water discharged into the Olt River, using a water-water vapour compression heat pump.

Figure 3 presents the insertion of the heat pump in the functioning scheme of the geothermal station [11]. The heat pump works only in the cold season, when the thermal power required by the district heating system overcomes the thermal power of the existing plate heat exchanger from the geothermal station. In the heat pump evaporator, the geothermal water is cooled up to a temperature of about $30{ }^{\circ} \mathrm{C}$, after which it flows into the Olt River. The condenser of the heat pump operates in parallel with the plate heat exchanger of geothermal water; it multiplies the thermal fluid flow sent into the heating system and therefore, the heat provided to the system increases. In this way, about two-third can be covered from the estimated thermal energy needs; the rest of the thermal energy and the peaks can be covered using oil-fired hot water boilers or using the thermal energy recovered from the combustible gases contained in the geothermal water. To reach the temperature range that corresponds to the thermal energy supply system, the heat pump must operate with an evaporating temperature of about $25^{\circ} \mathrm{C}$ and with a condensation temperature over $90{ }^{\circ} \mathrm{C}$. From the currently accepted refrigerants, refrigerants R123 and R245fc, and some hydrocarbons meet these requirements. The best choice in the given conditions is the high temperature refrigerant R123, which has high stability, is fireproof and nonexplosive, and has the advantages of low pressure in installations and small compression ratios. The option regarding R123 is also justified by its reduced environmental impact, having an Ozone Depleting Potential (ODP) close to zero $(\mathrm{ODP}=0.02)$ and a Global Warming Potential $(\mathrm{GWP})$ having a very small value $(\mathrm{GWP}=120)$. For the thermodynamic cycle of the one stage heat pump, the efficiency of R123 cycle is better than with other agents [12].

The temperature variation in the evaporator of the geothermal water was considered $50 / 30{ }^{\circ} \mathrm{C}$ and the temperature variation of the thermal fluid prepared in the condenser $45 / 85^{\circ} \mathrm{C}$. For the maximum available volume flow of geothermal water of $10 \mathrm{l} / \mathrm{s}$, the thermal power of the evaporator is $840 \mathrm{~kW}$; the thermal power of the condenser is $1,060 \mathrm{~kW}$ and the electric power consumption of the compressor is $230 \mathrm{~kW}$. These results were obtained by a simulation of the heat pump working, with R123 as refrigerant, made in EES software.

The Coefficient of Performance (COP) of the heat pump is about 4.7 , leading to a cost price of thermal energy delivered in the heating system about $0.02 € / \mathrm{kWh}$, the price of domestic electric energy being considered $0.08 € /$ $\mathrm{kWh}$. Taking into account the maintenance cost and depreciation rate of the investment, a cost price of energy of $0.03 € / \mathrm{kWh}$ is estimated comparable to that of the geothermal energy currently delivered in the centralized heating system. As a result, the heating system will receive a "clean" thermal power of about 2,880 kW $(2,650 \mathrm{~kW}$ from the geothermal energy and $230 \mathrm{~kW}$, the electrical energy for driving the heat pump compressor).

By adopting this solution, the geothermal station covers in a proportion of about $72 \%$ the thermal energy required by the district heating system. Considering standard cold 
Fig. 3 Scheme of the geothermal station with HP heat recovery: $G W W$ geothermal water well, $D T$ degassing tank, $P S$ pumping station, WPHE plate heat exchanger for domestic hot water, $H P H E$ plate heat exchanger for heating, $H P$ water/water heat pump

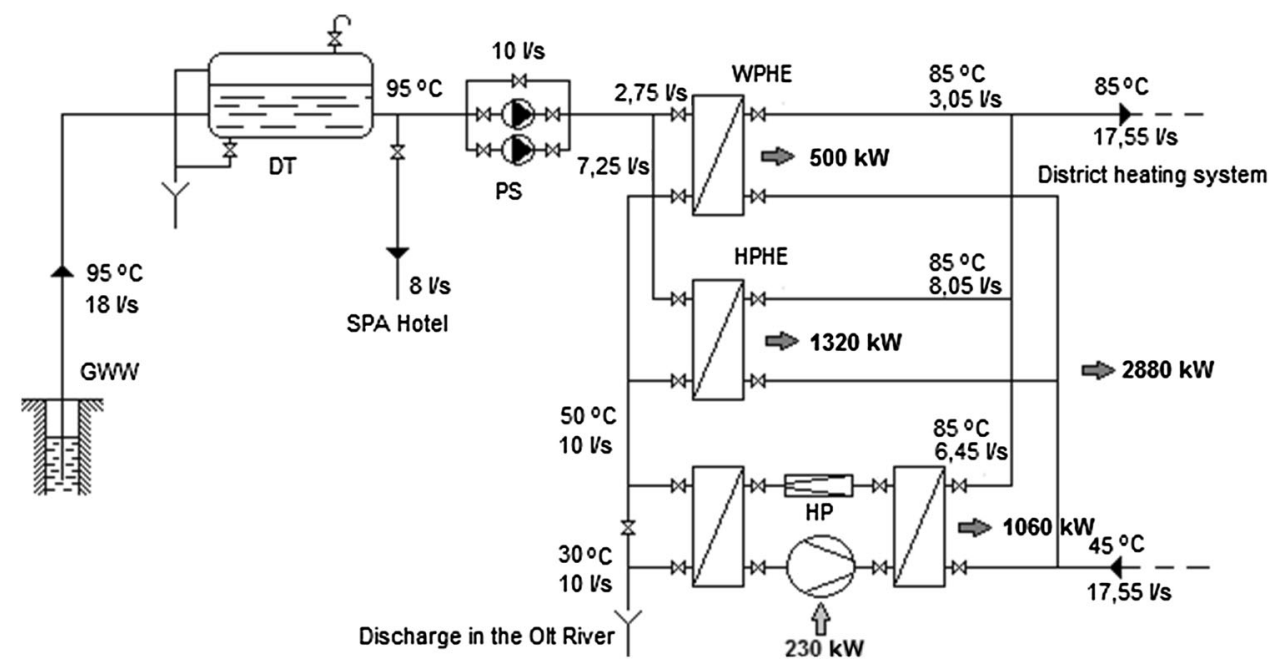

season conditions, it generates an important economy of liquid fuel and, at the same time, an important reduction of carbon dioxide, and other polluting gases. In reality, the effect is more important because these estimations correspond to extreme climatic conditions, this situation having a little probability in the area. Considering a value of the electricity production efficiency-in classical thermal power stations-of 30-33\%, the primary energy ratio (PER) of the system, compared to the primary energy consumption from classical sources, can be determined with the expression:

PER $=\frac{\dot{Q}}{\frac{\dot{Q}_{\mathrm{H}}^{\mathrm{HWB}}}{\eta_{\mathrm{HWB}}}+\frac{P_{\mathrm{C}}}{\eta_{\mathrm{E}}}}$

where $P_{\mathrm{C}}[\mathrm{kW}]$ is the effective power required for the compressor driving, $\eta_{\mathrm{E}}$ is the efficiency of the electricity production in thermo power stations $\left(\eta_{\mathrm{E}}=0.30-0.33\right.$ and the other quantities are as defined above [11]. Considering $\dot{Q}=4000 \mathrm{~kW}, \dot{Q}_{\mathrm{H}}^{\mathrm{HWB}}=1120 \mathrm{~kW}$ and $P_{\mathrm{C}}=230 \mathrm{~kW}$, the obtained value is PER $=2.1$, which means an improvement of $133 \%$, compared to the previous situation, when the thermal energy for heating was produced using only liquid fuel (in this case PER $=\eta_{\mathrm{HBW}} \cong 0.90$ ).

If the electricity required by the heat pump is also produced from renewable energy sources (like the microhydraulic potential of the Olt River), then the system can operate almost the entire cold season only using "green" energy. In this case, the liquid fuel hot water boilers cover only eventual peaks or emergencies.

\section{Full recovery of the combustion potential of the gases,} using a micro gas turbine cogeneration unit

The small gas turbine cogeneration units, using gaseous or liquid fuel, have become commercial and operational around the year 2000. The efficiency of electricity production is about $28-30 \%$, and the global efficiency of the electricity and thermal energy combined production is about $75-78 \%$ (for the exhaust gases temperature of $\left.90{ }^{\circ} \mathrm{C}\right)$.

Some of the advantages of the gas turbine units are the very low polluting emissions, without chemical treatment or afterburning; one single element in motion-the impeller; air bearings; cooling with air; the possibility to use a great variety of liquid and gaseous fuels, including gases with a high content of hydrogen sulphide $\left(\mathrm{H}_{2} \mathrm{~S}\right)$. Also, the following may be mentioned: the optimization for permanent operation at full load $(24 \times 7)$; the ability to track the load variations of the consumer; working unattended and automatic; requirement for less space; maintenance at great intervals of time (about $8,000 \mathrm{~h}$ ) and guaranteed operation over $80,000 \mathrm{~h}$; low level of noise (60-70 dBA at distance of $1 \mathrm{~m}$ ). The main disadvantages of the use of micro gas turbine cogeneration units are their electric lower efficiency, and their price still high.

Figure 4 presents the operating scheme of a micro gas turbine cogeneration unit of MT 250 type [13]. The compression ratio is about 6 ; the value of internal efficiency of the compressor is about $80-85 \%$ and, the temperature of compressed air of about $250{ }^{\circ} \mathrm{C}$. The combustion chamber operates with a factor of air excess about 5-6, the exhaust gases having an oxygen content of about $15 \%$ and a very low content of polluting emissions. The output temperature from the combustion chamber is about $920-950{ }^{\circ} \mathrm{C}$. The rotation speed of the turbine-compressor group is very high: $65,000-70,000 \mathrm{rpm}$, the exhaust gas temperature is of about $500{ }^{\circ} \mathrm{C}$ and the value of the internal turbine efficiency is about $85-90 \%$. After the heat recovery exchanger, the temperature of the exhaust gases is about $280{ }^{\circ} \mathrm{C}$ and the temperature of the compressed air is about $460{ }^{\circ} \mathrm{C}$, the value of the internal recovery rate being $0.7-0.8$. The 
Fig. 4 Operating scheme of a micro gas turbine cogeneration unit

Fig. 5 Scheme of the heating geothermal station using heat pump and micro gas turbine cogeneration unit: WPHE, $H P H E$ plate heat exchangers, $H P$ heat pump, GMTCU micro gas turbine cogeneration unit, $C T$ cooling tower

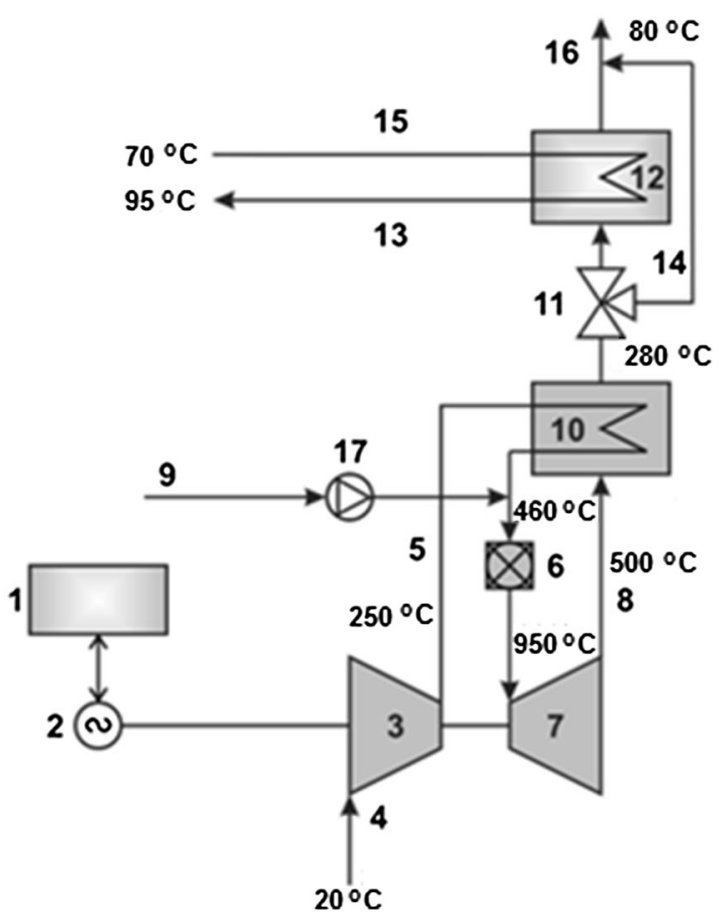

LEGEND

1. Power converter and command and control unit

2. High frequency electric generator

3. Centrifugal turbo-compressor

4. Air admission

5. delivery pipe of compressor

6 . Annular combustion chamber

7. Micro gas turbine

8. Exaust pipe of turbine

9. Intanke fuel pipe

10. Internal recovery heat exchanger

11. By-pass valve

12. External recovery heat exchanger (hot water boiler)

13. Hot water delivery pipe

14. By-pass pipe

15. Hot water return pipe

16. Exhaust manifold

17. Gas compressor

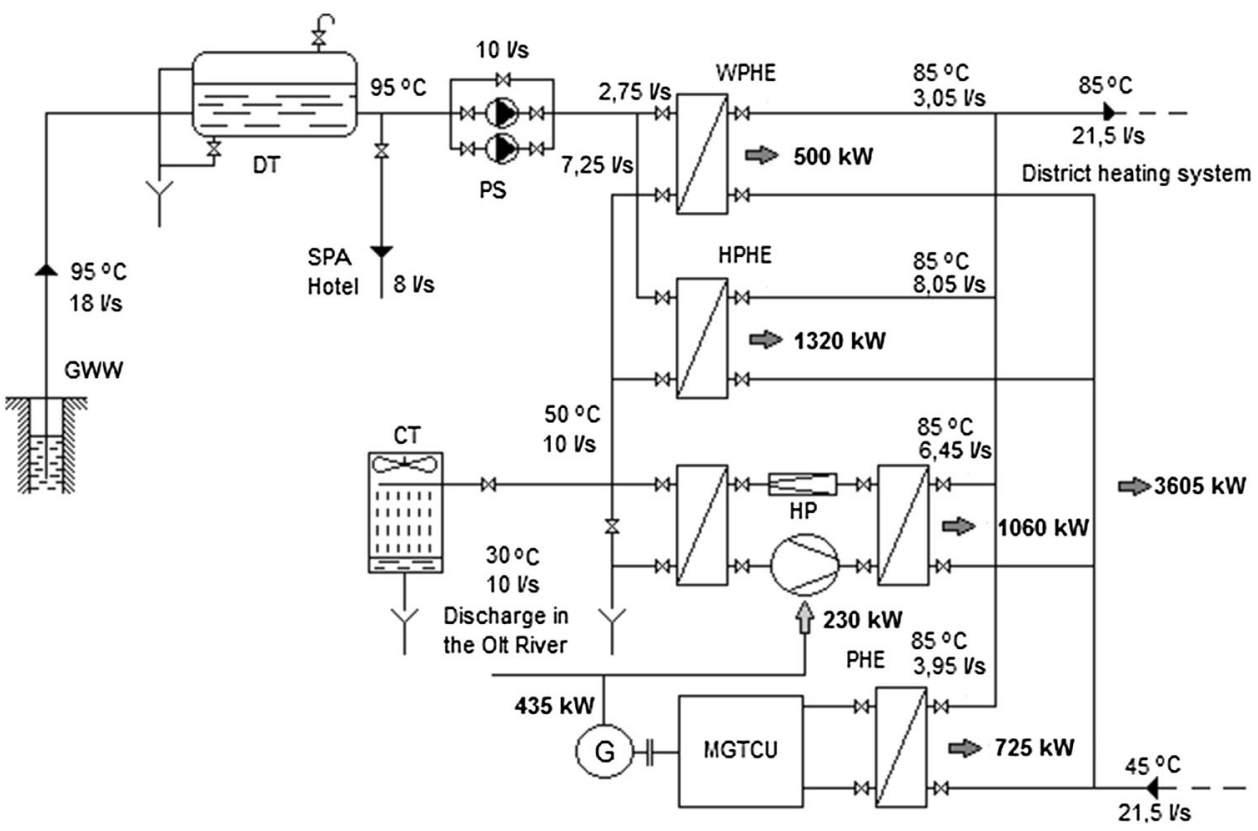

exhaust gases are crossing the hot water boiler, which prepares hot water at $70 / 95{ }^{\circ} \mathrm{C}$. The hot water boiler has on the gases side an electronic controlled pass valve, its thermal load being according to consumer needs. The overall efficiency of the micro gas turbine cogeneration unit is about $45 \%$, being greater than the efficiency of the separate production of electricity and heat [14].

Figure 5 depicts the scheme proposed to recover the energy potential of the gases separated from the geothermal water produced by drill No. 1009 Calimanesti, using a heat pump and a micro gas turbine cogeneration unit.

The cogeneration unit operates in parallel with the geothermal station, increasing the mass flow of the agent sent into the district heating system. The gas flow obtained from geothermal water allows a thermal power of $725 \mathrm{~kW}$ and an electrical power of $435 \mathrm{~kW}$. The electricity obtained is sufficient for the operation of the heat pump and of the pumps for circulation. For a better flexibility, it is 
advantageous to install multiple units of lower power (for example, multiple units of $100 \mathrm{~kW}$ each).

An economic analysis has been made for a micro gas turbine cogeneration unit of $100 \mathrm{~kW}$, in according to scheme depicted in Fig. 4 [15]. The authors of this analysis took into account the following input data: the specific capital cost-1,500 €/kW (including transport and fitting); operating and maintenance cost- $0.011 € / \mathrm{kW}$; the tariff of natural gas- $0.29 € / \mathrm{m}_{\mathrm{N}}^{3}$; the tariff of domestic electricity$0.08 € / \mathrm{kWh}$; the tariff of thermal energy for heating$0.064 € / \mathrm{kWh}$. In addition, it was considered the discount rate-12\%; the planned payback period-7 years; the internal heat recovery rate of the thermodynamic cycle0.63 ; the lifetime expectance-15 years.

Within this analysis has been calculated the following economic indicators:

- Payback time $\left(T_{\mathrm{s}}\right)$ calculated as Cost of project/annual cash inflow.

- Net Present Value (NPV) calculated as difference between the present value of cash inflows and the present value of cash outflows:

$\mathrm{NPV}=\sum_{t=1}^{n} \frac{C_{\mathrm{t}}}{(1+r)^{t}}-C_{0}[€]$

where $C_{0}[€]$ is the initial investment; $C_{\mathrm{t}}[€]$ is the annual net cash flow; $r$ is the discount rate and $n$ is the number of considered years (lifetime).

- Internal Rate of Return (IRR) calculated as discount rate at which the net present value of costs (negative cash flows) of the investment equals the net present value of the benefits (positive cash flows) of the investment $(\mathrm{NPV}=0)$.

The conditions for a good micro gas turbine unit, indicating the satisfaction of the investor, are: NPV $>0$, IRR $>r$ and $T_{\mathrm{s}}>$ lifetime. The obtained values for these economic indicators in quoted work [15] were the following: $\mathrm{NPV}=41130 €, \mathrm{IRR}=14.8 \%$ and $T_{\mathrm{s}}=7.5$ years.

In reality, the economic indicators have much better values because the fuel costs are nil, the fuel being the gas recovered from the geothermal water. These results demonstrate that such a solution is perfectly feasible.

\section{Conclusions}

The thermal potential of geothermal water and contained combustible gases of the analysed area is a significant primary energy reserve. It may allow the operation of an autonomous district heating system of Caciulata-Calimanesti-Cozia localities.
The proposed solution for an advanced exploitation of this potential concerns the use of the heat pump, which can cover over $70 \%$ of the peak heat required in winter; the rest of the peak (for extreme weather conditions) can be produced in liquid fuel fired hot water boilers or using the energy recovered from the combustible gases. Using direct burning or small cogeneration units, it is possible to recover the full thermal potential of the combustible gases. The use of micro gas turbine unit using the combustible gases contained in geothermal water emphasizes very well the advantages of cogeneration. Worthy to note is that this solution allows a great operational flexibility due to the selective use of the heat pump. Thus, in summer, when the thermal heating load decreases, the heat pump operates partially; in this case, the geothermal water flow of the well shrinks significantly, thus contributing to conservation of the geothermal resource. The use of micro gas turbine cogeneration unit leads to a great overall heating system efficiency and an autonomous operation. The payback time of about 7 years, the internal rate of return greater than the annual discount rate, the low maintenance, and the high reliability make this solution be interesting for a potential investor. The equipment may also be designed with a modular function (more units with small capacities), allowing a dynamic response according to the variable needs of the urban consumers. Thus, the geothermal resource conservation can be ensured, in respect with the exigency imposed by the requirement of sustainable development of the area.

Acknowledgments The authors would like to thank their colleagues Negreanu P.G and Oprea I, from the Department of Heat Engineering, Internal Combustion Engines, Thermal and Refrigerating Equipments, "Politehnica" University from Bucharest, that, with great kindness, agreed to quote and use in this article the results of the their work presented at the Symposium COFRET'12, Sozopol, Bulgaria (2012) [15].

Open Access This article is distributed under the terms of the Creative Commons Attribution License which permits any use, distribution, and reproduction in any medium, provided the original author(s) and the source are credited.

\section{References}

1. European Commission-Directorate General for Energy: renewables make the difference. Publications Office of the EU, Luxembourg (2011)

2. Entchev, E., Yang, L., Szadkowski, F., Armstrong, M., Swinton, M.: Application of hybrid micro-cogeneration system-thermal and power energy solutions for Canadian residences. Energy Build. 60, 345-354 (2013)

3. Østergaard, P.A., Lund, H.: A renewable energy system in Frederikshavn using low-temperature geothermal energy for district heating. Appl. Energy 88, 479-487 (2011) 
4. Rosca, G.M., Antics, M.: Numerical model of the geothermal well located at the University of Oradea campus. In: Proceedings of the 24th Workshop on Geothermal Reservoir Engineering, Stanford University, Stanford, California, USA, 25-27 January 1999

5. Marasescu, D., Mateiu, A.: The Exploitation of the potential of low enthalpy geothermal resources for heating supply of localities. ISPE Bulletin 57(2), 13-27 (2013)

6. National Research and Development Institute for Energy (ICEMENERG): Study on assessing the current energy potential of renewable energy in Romania (solar, wind, biomass, micro hydro, geothermal), to identify the best locations for development investment in unconventional electricity (in Romanian). Ministry of Research Study for Economy, Bucharest (2006)

7. Romanian Government: HG 1535/2003-decision approving the strategy for the use of renewable energy. Official Journal of Romania, 8, January 07, Bucharest (2004)

8. Antal, C., Rosca, M.: Current status of geothermal development in Romania. In: Proceedings of the 30th Anniversary Workshop, UN University, Reykjavík, 26-27 August 2008 (Available on http://www.os.is)

9. Burchiu, N., Burchiu, V., Gheorghiu, L.: Centralized heat supply system based on geothermal resources in the city of
Călimăneşti-Valcea County (in Romanian). In: Proceedings of the 4th National Conference of Hydropower Engineers from Romania-Dorin Pavel, Paper Nr. 3.10, Bucharest (2006)

10. National Authority of Regulating and Monitoring for Community Services of Public Utilities (ANRSC): Data on the state of energy services (in Romanian). http://www.anrsc.ro

11. Bianchi, A.M., Dimitriu, S., Băltăreţu, F.: Solutions for updating the urban electric power and heat supply systems, using geothermal sources. Termotehnica, An XV 2, 49-60 (2011)

12. Liangdong, M., Jili, Z., Shuian, Z.: Thermodynamic cycle analysis of high temperature refrigerants in a multistage heat pump system. In: Proceedings of Int. Conf. of MACE, pp. 1515-1520, Wuhan, China (2010)

13. FLEX TURBINE ${ }^{\mathrm{TM}}:$ Technical specification MT250 series Micro Turbine. http://www.flexenergy.com

14. Khisamutdinov, N.: Gas engine and gas turbine cogeneration units. EEICT Sbornik 03, Brno, Czech (2010)

15. Negreanu, P.G., Oprea, I.: Thermodynamic and economic analysis of the micro turbines for cogeneration. In: Proceedings of COFRET'12 Symposium, Sozopol, Bulgaria (2012) 